\title{
Pemberian Ekstrak Akar Pasak Bumi Meningkatkan Kualitas Spermatozoa Domba Waringin
}

\author{
(THE ADMINISTRATION OF EURYCOMA LONGIFOLIA ROOT EXTRACT \\ IMPROVE WARINGIN SHEEP SPERMATOZOA QUALITY)
}

\author{
Amalia Sutriana ${ }^{1}$, Mira Ayu Lestari Hasibuan², Nurhazimah ${ }^{2}$, \\ Teuku Armansyah ${ }^{1 *}$, Tongku Nizwan Siregar ${ }^{3}$, Budianto Panjaitan $^{4}$, \\ Hafizuddin $^{3}$, Arman Sayuti ${ }^{4}$, Dwinna Aliza ${ }^{5}$, Rosmaidar ${ }^{1}$ \\ ${ }^{1}$ Laboratorium Farmakologi, ${ }^{2}$ Program Studi Pendidikan Dokter Hewan, \\ ${ }^{3}$ Laboratorium Reproduksi, ${ }^{4}$ Laboratorium Klinik, ${ }^{4}$ Laboratorium Patologi, \\ Fakultas Kedoktean Hewan, Universitas Syiah Kuala, \\ Jl. Teungku Hasan Krueng Kalee, No. 4, Kopelma Darussalam \\ Banda Aceh, Aceh, Indonesia, 23111 \\ Telpon: (0651)7551536, *Email: t_armansyah@unsyiah.ac.id
}

\begin{abstract}
ABSTRAK
Penelitian ini bertujuan mengetahui pengaruh pemberian ekstrak akar pasak bumi (Eurycoma longifolia Jack) terhadap peningkatan konsentrasi testosteron domba Waringin. Dalam penelitian ini digunakan dua ekor domba waringin jantan berumur \pm 4 tahun. Penelitian ini merupakan penelitian eksperimen dengan menggunakan rancangan pola bujur sangkar latn 2 x 2 sehingga hewan percobaan diberi perlakuan $20 \mathrm{~mL}$ akuades per oral sebagai kontrol (P1) dan $20 \mathrm{~mL}$ larutan yang mengandung 45 $\mathrm{mg} / \mathrm{kg}$ bobot badan ekstrak pasak bumi yang diberikan per oral (P2). Perlakuan diberikan selama enam hari pada pukul 09.00 WIB. Pada bulan ke-1 domba pertama mendapat perlakuan P1 sedangkan domba kedua mendapat perlakuan P2. Sebaliknya, pada bulan ke-2 domba pertama mendapat perlakuan P2 sedangkan domba kedua mendapat perlakuan P1. Koleksi darah untuk pemeriksaan konsentrasi hormon testosteron dilakukan lima jam setelah pemberian ekstrak akar pasak bumi (Eurycoma longifolia Jack). Analisis konsentrasi testosteron dilakukan menggunakan metode enzyme linked immunosorbent assay (ELISA) yang diukur pada hari 1, 3 dan 6. Data yang diperoleh dianalisis dengan uji sidik ragam pola bujur sangkar latin. Hasil analisis statistika menunjukkan bahwa volume semen, motilitas spermatozoa, viabilitas spermatozoa dan abnormalitas spermatozoa pada domba yang diberikan ekstrak akar pasak bumi (E. longifolia Jack) menunjukkan perbedaan yang signifikan $(\mathrm{P}<0,05)$ dibandingkan dengan kontrol namun konsentrasi testosteron tidak menunjukkan perbedaan yang signifikan $(\mathrm{P}>0,05)$. Disimpulkan bahwa pemberian ekstrak akar pasak bumi meningkatkan kualitas spermatozoa namun tidak menyebabkan peningkatan konsentrasi hormon testosteron pada domba waringin.
\end{abstract}

Kata-kata kunci: domba waringin; Eurycoma longifolia Jack; kualitas spermatozoa; testosteron

\begin{abstract}
The aim of this research was to evaluate the effect of pasak bumi (Eurycoma longifolia Jack) root extract administration on the improvement of Waringin sheep spermatozoa quality and testosterone concentration. This research was an experimental study using two Waringin sheep with $2 \times 2$ latin square design. In the first month, the sheep was given $5 \mathrm{~mL}$ aquadest as a control, while the in the second month, the respective sheep was given pasak bumi root extract at dose of $45 \mathrm{mg} / \mathrm{kg} / \mathrm{bw}$ in $20 \mathrm{~mL}$ aquadest. Semen collection and blood was carried out on days 1, 3 and 6 . Semen samples were collected using an electroejaculator five hours after treatment and color, consistency, $\mathrm{pH}$ volume, concentration, motility, viability, and spermatozoa abnormalities were observed. Testosterone concentration analysis was performed by using the enzyme linked immunosorbent assay (ELISA) method. Statistical analysis showed that semen volume, spermatozoa motility, spermatozoa viability and spermatozoa abnormality after administration of Eurycoma longifolia root extract showed significant differences $(\mathrm{P}<0.05)$ compared to control but did not increase testosterone concentration of Waringin sheep. It was concluded that the
\end{abstract}


administration of pasak bumi (Eurycoma longifolia Jack) root extracts improved the quality of Waringin sheep spermatozoa but did not increase testosterone concentration.

Keywords: Waringin sheep; Eurycoma longifolia Jack; spermatozoa quality; testosterone

\section{PENDAHULUAN}

Upaya untuk meningkatkan produktivitas domba dapat dilakukan melalui perbaikan efisiensi reproduksi. Perbaikan efisiensi reproduksi dapat dilakukan dengan implementasi teknologi inseminasi buatan (IB). Salah satu faktor yang memengaruhi keberhasilan IB adalah kualitas semen yang digunakan untuk proses pembekuan.

Beberapa laporan sebelumnya menunjukkan bahwa kualitas semen domba waringin relatif rendah. Domba waringin merupakan hasil dari persilangan dari beberapa jenis domba yaitu domba barbados yang berasal dari Karibia (Amerika latin), domba suffolk (Inggris), domba stcroix (Australia), dan domba lokal ekor tipis (Indonesia). Husnurrizal et al. (2021) melaporkan volume semen domba waringin adalah sebanyak $1,20 \pm 0,23 \mathrm{~mL}$. Jika dibandingkan dengan domba batur, domba lokal di Kabupaten Banjarnegara, volume semen domba waringin cenderung lebih sedikit. Nahriyanti et al. (2017) melaporkan rata-rata volume domba batur pada pen mating adalah $1,28 \mathrm{~mL}$, sedangkan pada flock mating adalah 1,25 mL. Motilitas spermatozoa domba waringin relatif sangat rendah. Husnurrizal et al. (2021) melaporkan bahwa rata-rata motilitas spermatozoa domba waringin adalah $66,68 \pm 5,43 \%$. Motilitas spermatozoa ini lebih rendah bila dibandingkan dengan laporan Bintara et al. (2018) pada domba ekor gemuk dengan motilitas spermatozoa sebesar $78 \pm 3 \%$. Kualitas spermatozoa sangat dipengaruhi oleh konsentrasi testosteron (Asmarasari dan Tiesnamurti, 2016).

Konsentrasi testosteron domba waringin belum pernah dilaporkan. Konsentrasi testosteron domba garut dan domba malin masing-masing adalah $5,28 \pm 3,11 \mathrm{ng} / \mathrm{mL}$ dan 2,31 $\pm 0,42 \mathrm{ng} / \mathrm{mL}$ (Wahid dan Yunus, 1995). Upaya alternatif untuk meningkatkan kualitas spermatozoa dan konsentrasi testosteron domba waringin adalah melalui pemberian ekstrak akar pasak bumi. Ekstrak pasak bumi telah dilaporkan dapat meningkatkan kualitas spermatozoa hewan model (Juniarto, 2010; Bogar et al., 2016) dan kambing peranakan etawa (Pratomo dan Yudi, 2016). Ekstrak akar pasak bumi telah dilaporkan dapat meningkatkan konsentrasi testosteron tikus wistar (Hayati et al., 2012). Namun, belum terdapat laporan penggunaan ekstrak pasak bumi untuk meningkatkan kualitas spermatozoa dan konsentrasi testosteron pada domba waringin. Penelitian ini bertujuan mengetahui pengaruh pemberian ekstrak akar pasak bumi (Eurycoma longifolia Jack) terhadap kualitas spermatozoa dan konsentrasi testosteron domba waringin

\section{METODE PENELITIAN}

Dalam penelitian ini digunakan dua ekor domba waringin jantan berumur 3-4 tahun dengan bobot badan 28 dan $35 \mathrm{~kg}$. Penelitian ini merupakan penelitian eksperimen dengan menggunakan rancangan pola latin square $2 \mathrm{x}$ 2 sehingga hewan percobaan mendapatkan 20 $\mathrm{mL}$ akuades per oral sebagai kontrol (P1) dan mendapatkan $20 \mathrm{~mL}$ larutan yang mengandung ekstrak akar pasak bumi per oral sebagai perlakuan (P2).

\section{Aklimatisasi}

Sebelum diberikan ekstrak akar pasak bumi, domba waringin jantan dipelihara selama dua minggu pada kandang berukuran $1 \mathrm{~m} \times 1 \mathrm{~m}$ untuk satu individu. Pada masa aklimatisasi domba waringin diberikan vitamin B kompleks secara intramuskuler (Astuti et al., 2017), dan antiparasit menggunakan ivermectin secara subkutan (Puspitasari et al., 2015). Pakan berupa rumput-rumputan, konsentrat dan air minum diberikan secara ad libitum. Pada bulan ke-1, domba pertama mendapat perlakuan P1 sedangkan domba kedua mendapat perlakuan P2. Sebaliknya, pada bulan ke-2, domba pertama mendapat perlakuan P2 sedangkan domba kedua mendapat perlakuan $\mathrm{P} 1$.

\section{Pembuatan Ekstrak Akar Pasak Bumi}

Akar pasak bumi yang telah dikumpulkan dicuci dengan air mengalir, akar pasak bumi yang telah dikering-anginkan dipotong kecilkecil dengan pisau kemudian diblender hingga halus dan berupa serbuk. Selanjutnya serbuk pasak bumi dilakukan maserasi dengan 
menggunakan etanol 96\%. Sebanyak $1 \mathrm{~kg}$ serbuk pasak bumi ditambah etanol $96 \%$ selanjutnya diaduk selama 30 menit, dan didiamkan selama 24 jam. Hasil filtrat ditampung setiap 24 jam sekali sampai enam kali penampungan kemudian diuapkan dengan vaccum rotatory evaporator dengan suhu $50^{\circ} \mathrm{C}$. Ekstrak yang didapatkan diuapkan menggunakan oven pada suhu $50^{\circ} \mathrm{C}$ dan ekstrak yang dihasilkan disimpan dalam refrigerator sebelum digunakan.

\section{Induksi Ekstrak Akar Pasak Bumi}

Pola perlakuan pemberian pasak bumi sesuai metode Pratomo dan Yudi (2016). Domba pada $\mathrm{P} 1$ diberikan $20 \mathrm{~mL}$ akuades selama enam hari sedangkan domba pada P2 diberikan ekstrak akar pasak bumi dengan dosis $45 \mathrm{mg} /$ BB dalam $20 \mathrm{~mL}$ akuades selama enam hari. Seluruh perlakuan dilakukan pada pukul 09.00 WIB. Selang setiap perlakuan pada tiap ekor domba adalah sama, satu bulan.

\section{Penampungan Semen}

Semen dikoleksi menggunakan elektroejakulator. Sebelum probe dimasukkan ke dalam rektum, preputium dan daerah sekitarnya dibersihkan dengan $\mathrm{NaCl}$ fisiologis dan dikeringkan dengan kertas tisu, dan rambut di sekitar preputium dipotong. Penampungan semen dilakukan pada hari ke-1, 3, dan 6 pada pukul 14.00 WIB sesuai metode Pratomo dan Yudi (2016).

\section{Pemeriksaan Kualitas Semen}

Pemeriksaan kualitas semen meliputi pemeriksaan makroskopis dan mikroskopis. Pemeriksaan makroskopis yang dilakukan terdiri atas pemeriksaan volume, warna, $\mathrm{pH}$, dan konsistensi sedangkan pemeriksaan mikroskopis meliputi motilitas dan konsentrasi spermatozoa (Mughniati et al., 2018), viabilitas spermatozoa (WHO, 1999) dan abnormalitas spermatozoa (Soehadi dan Arsyad, 1983).

\section{Pemeriksaan Sampel Darah}

Pengambilan sampel darah diambil pada pada hari ke-1, 3, dan 6 pada pukul $14.00 \mathrm{WIB}$ sesuai petunjuk Pratomo dan Yudi (2016). Sampel darah diambil sebanyak $5 \mathrm{~mL}$ dengan menggunakan spuit $5 \mathrm{~mL}$ pada vena jugularis. Sebelumnya daerah kulit di atas vena jugularis diberikan alkohol 70\% sebagai desinfektan. Selanjutnya dimasukkan ke dalam microtube, kemudian darah disentrifugasi dengan kecepatan 3.000 rpm selama 15 menit. Serum tersebut dianalisis konsentrasi hormon testosteron menggunakan teknik enzim linked immunosorbent assay (ELISA). Sebelum diperiksa, serum disimpan dalam freezer bersuhu $-20^{\circ} \mathrm{C}$ sampai dilakukan pengukuran.

\section{Pemeriksaan Kadar Hormon Testosteron}

Serum dimasukkan kedalam tiap sumur microplate ELISA sebanyak $25 \mu \mathrm{L}$ larutan standar, sampel, dan kontrol, lalu ditambahkan 200 iL reagen konjugat enzim HPR testosteron ke dalam tiap sumur. Selanjutnya dikocok selama 10 detik dan diinkubasi selama 60 menit pada suhu ruang. Setelah diinkubasi larutan dibilas sebanyak tiga kali dengan menambahkan larutan pencuci sebanyak $300 \mu \mathrm{L}$ pada setiap sumur. Sebelum diinkubasi kembali selama 15 menit pada suhu ruang, dimasukkan sebanyak $100 \mu \mathrm{L}$ larutan substrat solution pada tiap sumur. Tahap selanjutnya menambahkan $50 \mu \mathrm{L}$ stop solution ke tiap sumur untuk menghentikan reaksi enzimatik. Nilai dibaca pada absorbansi $450 \pm 10 \mathrm{~nm}$ dengan ELISA reader dalam waktu 10 menit setelah ditambahkan stop solution (Rahayu et al., 2017). Data yang diperoleh dianalisis menggunakan uji sidik ragam dengan perangkat lunak SPSS versi 16.0.

\section{HASIL DAN PEMBAHASAN}

Pengamatan secara makroskopis memperlihatkan warna semen domba waringin berwarna putih krem, dan konsistensi kental. Hal ini sesuai dengan pendapat Toelihere (1993), bahwa semen domba normal berwarna putih susu sampai putih krem serta konsistensi agak kental sampai kental. Campuran warna kemerahan dan coklat pada semen menandakan semen terkontaminasi oleh darah dan warna hijau menandakan adanya bakteri dalam semen (Kusumawati et al., 2017). Hasil pemeriksaan volume, konsentrasi, motilitas, viabilitas, abnormalitas spermatozoa, dan konsentrasi testosteron domba waringin setelah pemberian ekstrak pasak bumi pada hari ke-1, 3 dan 6 disajikan pada Tabel 1.

Pada Tabel 1, diketahui bahwa volume semen domba waringin pada hari ke-1, 3, dan 6 berkisar 1,50-1,85 mL. Hasil penelitian ini masih berada pada kisaran normal sesuai pendapat Toelihere (1993) yakni volume normal semen domba berkisar 0,50-2,50 mL. Hasil uji sidik ragam menunjukkan pemberian ekstrak 
Tabel 1. Rataan volume, konsentrasi, motilitas, viabilitas, abnormalitas spermatozoa, dan konsentrasi testosteron domba waringin dengan perlakuan pasak bumi pada hari ke-1, 3 , dan 6 .

\begin{tabular}{|c|c|c|c|c|c|c|}
\hline \multirow{2}{*}{ Perlakuan } & \multicolumn{2}{|c|}{ Hari ke- 1} & \multicolumn{2}{|c|}{ Hari ke-3 } & \multicolumn{2}{|c|}{ Hari ke-6 } \\
\hline & $\mathrm{K}$ & $\mathrm{P}$ & $\mathrm{K}$ & $\mathrm{P}$ & $\mathrm{K}$ & $\mathrm{P}$ \\
\hline Volur & $1,10 \pm 0,56^{\mathrm{a}}$ & $1,7 \pm 0,42^{b}$ & $1,30 \pm 0,07^{\mathrm{a}}$ & $1,65 \pm 0,49 \mathrm{~b}$ & $0,70 \pm 0,42^{\mathrm{a}}$ & $1,70 \pm 0,14^{b}$ \\
\hline Konsentrasi $\left(10^{6} / \mathrm{ml}\right)$ & $590,00 \pm 15,55^{\mathrm{a}}$ & $783,50 \pm 25,24^{\mathrm{a}}$ & $665,00 \pm 13,43^{\mathrm{a}}$ & $842,50 \pm 2,22^{\mathrm{a}}$ & $730,00 \pm 14,84^{\mathrm{a}}$ & $807,50 \pm 81,31^{\mathrm{a}}$ \\
\hline Motilitas (\%) & $71,00 \pm 2,12^{\mathrm{a}}$ & $81,25 \pm 4,59 b$ & $58,25 \pm 31,46^{\mathrm{a}}$ & $88,25 \pm 4,59^{b}$ & $75,00 \pm 0,00^{\mathrm{a}}$ & $93,25 \pm 1,76^{b}$ \\
\hline Viabilitas(\%) & $75,55 \pm 6,62^{\mathrm{a}}$ & $89,92 \pm 5,28 \mathrm{~b}$ & $82,82 \pm 1,37^{\mathrm{a}}$ & $93,10 \pm 0,40^{b}$ & $82,68 \pm 3,18^{\mathrm{a}}$ & $93,47 \pm 2,71^{b}$ \\
\hline Abnormalitas(\%) & $16,37 \pm 0,22^{\mathrm{a}}$ & $9,910 \pm 0,57^{b}$ & $18,49 \pm 1,03^{\mathrm{a}}$ & $11,26 \pm 3,22^{b}$ & $20,34 \pm 1,52^{\mathrm{a}}$ & $10,97 \pm 0,76^{\mathrm{b}}$ \\
\hline Testosteron (ng/mL) & $7,71 \pm 0,79^{\mathrm{a}}$ & $14,79 \pm 18,34^{\mathrm{a}}$ & $12,9 \pm 7,67^{\mathrm{a}}$ & $7,22 \pm 4,90^{\mathrm{a}}$ & $6,42 \pm 6,22^{\mathrm{a}}$ & $4,05 \pm 2,14^{\mathrm{a}}$ \\
\hline
\end{tabular}

Keterangan: $\mathrm{K}=$ kontrol, $20 \mathrm{ml}$ akuades selama 6 hari; $\mathrm{P}=$ perlakuan, $45 \mathrm{mg} / \mathrm{bb}$ ekstrak akar pasak bumi dalam 20 ml akuades selama 6 hari. ${ }^{\text {a,b }}$ Superskrips yang berbeda pada baris yang sama menunjukkan perbedaan yang nyata $(\mathrm{P}<0,05)$.

akar pasak bumi terhadap volume semen domba waringin berpengaruh terhadap peningkatan volume semen $(\mathrm{P}<0,05)$ namun lama waktu pemberian tidak memengaruhi volume semen. Frydrychova et al. (2011) melaporkan hal yang sebaliknya bahwa pada ternak babi pemberian campuran beberapa ekstrak herbal yang mengandung pasak bumi menurunkan volume semen.

Efek pasak bumi terhadap konsentrasi spermatozoa tidak menunjukkan perbedaan yang signifikan $(\mathrm{P}>0,05)$ antara kelompok kontrol dan perlakuan pada waktu pemeriksaan hari ke-1; 3; 6 dengan nilai masing-masing adalah $5,90 \pm 1,55$ dan $7,83 \pm 2,52 ; 6,65 \pm 1,34$ dan $8,42 \pm 2,72 ; 7,30 \pm 1,48$ dan $8,07 \pm 8,13\left(10^{6} / \mathrm{mL}\right)$ seperti yang disajikan pada Tabel 1. Pratomo dan Yudi (2016) melaporkan hal yang sama bahwa konsentrasi spermatozoa kambing peranakan etawa (PE) tidak mengalami kenaikan yang signifikan meskipun konsentrasi hormon testosteron meningkat. Hasil yang berbeda diperoleh Bogar et al. (2016) bahwa konsentrasi spermatozoa tikus wistar mengalami kenaikan yang signifikan pada pemberian pasak bumi dengan dosis $600 \mathrm{mg} /$ kg/BB selama 50 hari. Perbedaan hasil ini kemungkinan diakibatkan oleh perbedaan dosis dan lama pemberian. Meskipun tidak terdapat perbedaan yang signifikan namun terlihat bahwa terdapat kecenderungan peningkatan konsentrasi spermatozoa antara kelompok kontrol dan perlakuan pada seluruh periode pemeriksaan. maupun persentase hidup spermatozoa kambing PE. Peningkatan konsentrasi spermatozoa akibat pemberian pasak bumi berkaitan dengan peningkatan konsentrasi hormon testosteron (Pratomo dan Yudi, 2016).

Efek akar pasak bumi terhadap motilitas spermatozoa menunjukkan perbedaan yang signifikan $(\mathrm{P}<0,05)$ antara kelompok kontrol dan perlakuan pada waktu pemeriksaan hari ke-1; 3 ; 6 dengan nilai masing-masing adalah $71,00 \pm 2,12$ dan $81,25 \pm 4,59 ; 58,25 \pm 31,46$ dan $88,25 \pm 4,59 ; 75,00 \pm 0,00$ dan $93,25 \pm 1,76 \quad$ (\%) seperti yang disajikan pada Tabel 1. Hasil penelitian ini sajalan dengan pendapat Bogar et al. (2016) yang menyatakan bahwa peningkatan motilitas spermatozoa berhubungan dengan pemberian akar pengaruh pasak bumi. Bogar et al. (2016) melaporkan bahwa pemberian 600 $\mathrm{mg} / \mathrm{kg}$ bb ekstrak herbal yang mengandung pasak bumi dapat meningkatkan motilitas spermatozoa tikus wistar hingga mencapai 95\%.

Efek pasak bumi terhadap viabilitas spermatozoa menunjukkan perbedaan yang signifikan $(\mathrm{P}<0,05)$ antara kelompok kontrol dan perlakuan, pada waktu pemeriksaan hari ke-1; 3; dan 6 dengan nilai masing-masing adalah $75,55 \pm 6,62$ dan $89,92 \pm 5,28 ; 82,82 \pm 1,37$ dan $93,10 \pm 0,40 ; 82,68 \pm 3,18$ dan $93,47 \pm 2,71 \quad$ (\%) seperti yang disajikan pada Tabel 1 . Hasil yang serupa telah dilaporkan oleh Pratomo dan Yudi (2016) bahwa persentase spermatozoa hidup cenderung mengalami kenaikan setelah pemberian pasak bumi. Nutrisi, energi serta membran plasma menjadi faktor yang dapat memengaruhi viabilitas dan motilitas spermatozoa. Membran plasma berfungsi melindungi organel sebagai pertukaran zat intraseluler dan ekstraseluler. Membran plasma 
yang rusak mengakibatkan proses metabolisme dan suplai energi terganggu mengakibatkan turunnya kualitas motilitas serta viabilitas spermatozoa (Prastika et al., 2018).

Morfologi abnormalitas spermatozoa dipengaruhi oleh pemberian pasak bumi $(\mathrm{P}<0,05)$. Abnormalitas spermatozoa antara kelompok kontrol dan perlakuan pada waktu pemeriksaan hari ke-1; 3; 6 masing-masing adalah $16,37 \pm 0,22$ dan $9,910 \pm 0,57 ; 18,49 \pm 1,03$ dan $11,26 \pm 3,22 ; 20,34 \pm 1,52$ dan $10,97 \pm 0,76$ (\%). Secara keseluruhan, persentase abnormalitas spermatozoa tidak melebihi $20 \%$ sebagai batas maksimal yang diperkenankan untuk inseminasi buatan. Hasil uji sidik ragam terhadap abnormalitas spermatozoa domba waringin berbeda nyata $(\mathrm{P}<0,05)$ menunjukkan bahwa pemberian ekstrak pasak bumi menurunkan angka abnormalitas spermatozoa pada hari ke1,3 dan 6. Menurut Garner dan Hafez (2000), abnormalitas spermatozoa domba berkisar antara 5-20\%. Hasil yang didapatkan masih tergolong normal.

Abnormalitas dibagi menjadi primer dan sekunder, abnormalitas primer terjadi akibat faktor keturunan, lingkungan yang buruk, dan terjadi akibat kegagalan dalam proses spermatogenesis (Afiati et al., 2015). Abnormalitas sekunder terjadi setelah proses perjalanan spermatozoa di saluran kelamin jantan dan kemungkinan besar disebabkan pada saat pewarnaan dalam proses pembuatan preparat ulas (Garner dan Hafez, 2000). Spermatozoa yang abnormal dapat menimbulkan gangguan dan hambatan pada saat fertilisasi sehingga menyebabkan rendahnya angka implantasi maupun kebuntingan (Yulnawati et al., 2013; Afiati et al., 2015).

Konsentrasi testosteron domba waringin kelompok kontrol dan perlakuan pada hari 1 ; $3 ; 6$ masing-masing adalah $7,71 \pm 0,79$ dan $14,79 \pm 18,34 ; 12,9 \pm 7,67$ dan $7,22 \pm 4,90 ; 6,42 \pm 6,22$ dan $4,05 \pm 2,14 \mathrm{ng} / \mathrm{mL}$. Hasil penelitian menunjukkan bahwa pemberian ekstrak akar pasak bumi dosis $45 \mathrm{mg} / \mathrm{kg}$ bobot badan tidak menunjukkan peningkatan yang signifikan terhadap konsentrasi testosteron domba waringin. Hasil yang serupa dilaporkan oleh Hayati et al. (2012), bahwa pemberian ekstrak akar pasak bumi pada tikus dosis $200 \mathrm{mg} / \mathrm{kg}$ badan selama enam hari masih belum mampu meningkatkan konsentrasi testosteron. Purwono et al. (2015) melaporkan bahwa pemberian ekstrak air akar pasak bumi dengan dosis $1,2 \mathrm{~g}$ pada pria disfungsi seksual selama tujuh hari juga tidak memengaruhi kadar testosteron. Kegagalan meningkatkan konsentrasi testosteron ini kemungkinan berkaitan dengan lama waktu pemberian yang belum cukup untuk mampu meningkatkan konsentrasi testosteron. Hayati et al. (2012) berhasil meningkatkan konsentrasi testosteron setelah diberikan ekstrak pasak bumi selama 49 hari. Meskipun demikian, alasan kegagalan peningkatan konsentrasi testosteron karena lama pemberian yang tidak cukup, dan hal tersebut tidak sesuai dengan laporan Pratomo dan Yudi (2016) yang membuktikan bahwa pemberian ekstrak pasak bumi sudah mampu meningkatkan konsentrasi testosteron pada saat pemberian hari ke-3 dan ke-6 .

Pada hari ke-1 menunjukkan kecenderungan peningkatan konsentrasi testosteron domba waringin yang diberikan ekstrak akar pasak bumi. Pratomo dan Yudi (2016) melaporkan hal yang serupa bahwa kambing PE yang diberikan ekstrak akar pasak bumi dosis $90 \mathrm{mg} / \mathrm{kg}$ bobot badan selama enam hari mampu meningkatkan konsentrasi hormon testosteron. Hasil yang serupa juga dilaporkan Pratomo et al. (2012) bahwa pemberian ekstrak akar pasak bumi dengan dosis $18 \mathrm{mg} / 200 \mathrm{~g}$ bobot badan pada tikus putih selama tiga hari meningkatkan konsentrasi testosteron serum yang signifikan dibandingkan kontrol.

Pada hari ke-6, konsentrasi testosteron cenderung menurun pada kedua kelompok. Penurunan ini kemungkinan disebabkan oleh stres akibat koleksi semen dengan elektroejakulator pada hari ke-1 dan ke-3 sesaat sebelum koleksi darah. Wahyuni et al. (2015) menyatakan bahwa penurunan konsentrasi testosteron dapat disebabkan oleh faktor stres. Saat stres terjadi hambatan proses sekresi pada hipotalamus sehingga terganggunya produksi hormon yang mengakibatkan sel Leydig gagal dalam mensekresikan hormon testosteron. Konsentrasi testosteron menurun saat stres mengakibatkan sekresi glukokortikoid meningkat pada kelenjar adrenal sehingga diikuti meningkatnya sekresi adrenocorticotropic hormone (ACTH) oleh kelenjar hipofisis. Sekresi sel Leydig terhambat akibat dari glukokortikoid yang berikatan dengan reseptor sel Leydig menyebabkan konsentrasi testosteron turun (Ardana, 2015).

Secara umum peningkatan kualitas spermatozoa akibat pemberian ekstrak pasak bumi disebabkan kandungan bahan aktif yang ada pada pasak bumi yakni euricomalaton, 
amarolinda, isoprenoid, dan sterol dapat memengaruhi aktivitas membran sel hipofisis anterior untuk meningkatkan sekresi luteinizing hormone $(\mathrm{LH})$ dan follicle stimulating hormone (FSH). Peningkatan hormon LH dan FSH berdampak pada organ testis dan aktivitas membran testis sehingga afinitas reseptor $\mathrm{LH}$ pada sel Leydig meningkat. Hormon LH akan terikat pada reseptor dan merangsang pembentukan dan sekresi testosteron. Hormon FSH merangsang sel Sertoli dalam membentuk sex hormone binding globulin (SHBG) untuk mengikat testosteron. Peningkatan kadar testosteron meningkatkan proses spermatogenesis. Eurycomalaton dan amarolinda juga mampu memperbaiki afinitas membran reseptor terhadap enzim 5-á reductase yang berperan dalam konversi testosteron menjadi bentuk lebih poten yang diyakini dapat meningkatkan kejadian spermatogenesis dan terutama pada fase spermiogenesis (Bogar et al., 2016).

Peningkatan konsentrasi testosteron kemungkinan berkaitan dengan peningkatan hormon luteinizing hormone (LH). Zubir et al. (2011) membuktikan bahwa pemberian ekstrak pasak bumi pada tikus dengan dosis $25 \mathrm{mg} / \mathrm{kg}$ bobot badan dapat meningkatkan konsentrasi LH sebesar 17,8\% dan hormon testosteron sebesar 99,5\%. Pasak bumi mengandung senyawa eurikumanon yang menyebabkan peningkatan produksi testosteron (Juniarto, 2010). Ekstrak akar pasak bumi mengakibatkan aktivitas sel gonadotrop meningkat dan menghasilkan LH pada hipofisa. Pelepasan LH yang meningkat di dalam darah akan didistribusikan sampai sel-sel Leydig yang mengakibatkan peningkatan aktivitas sel-sel Leydig dalam memproduksi hormon testosteron (Pratomo et al., 2012).

Senyawa utama dari tanaman pasak bumi mampu memperbaiki afinitas membran reseptor sel dan enzim 5-a reductase yang mampu mengubah bentuk menjadi dehidrotestosteron. Dengan adanya afinitas membran dan enzim 5a reductase membantu testosteron untuk masuk ke dalam sel Leydig. Pelepasan protein tertentu (Hsp 90) disebabkan oleh testosteron/ dihydrotestosterone sehingga terjadinya ikatan dengan reseptor androgen yang berada di dalam sitoplasma. Kompleks reseptor-testosteron/ dihydrotestosterone memasuki inti sel dengan sekuens spesifik dari DNA. Terjadinya penempelan yang menginduksi sintesis mRNA kemudian akan meningkatkan proses spermatogenesis (Juniarto, 2010).

\section{SIMPULAN}

Pemberian ekstrak akar pasak bumi mampu meningkatkan kualitas spermatozoa namun tidak menyebabkan peningkatan konsentrasi hormon testosteron pada domba waringin.

\section{SARAN}

Diperlukan penelitian lanjutan dengan menggunakan sampel domba yang lebih banyak dengan pemberian ekstrak akar pasak bumi yang lebih lama.

\section{UCAPAN TERIMA KASIH}

Penulis mengucapkan terima kasih kepada Ketua LPPM Universitas Syiah Kuala atas persetujuannya terhadap usulan Penelitian Mandiri dan kepada Ketua UPT. Hewan Coba Fakultas Kedokteran Hewan Universitas Syiah Kuala atas fasilitas penelitian yang diberikan.

\section{DAFTAR PUSTAKA}

Afiati F, Yulnawati, Riyadi M, Arifiantini RI. 2015. Abnormalitas spermatozoa domba dengan frekuensi penampungan berbeda. Prosiding Seminar Nasional Biodiversitas Indonesia. 1(4): 930-934.

Ardana M. 2015. Pengaruh waktu pengambilan sampel darah terhadap pemeriksaan testosteron. J Trop Pharm 3(1):22-28.

Asmarasari SA, Tiesnamurti B. 2006. Evaluasi pertumbuhan dan reproduksi domba jantan St. croix. Seminar Nasional Teknologi Peternakan dan Veteriner. Badan Penelitian dan Pengembangan, Kementerian Pertanian, Bogor. Hlm. 382-384

Astuti KRK, Ardana IBK, Anthara MS. 2017. Efek ovicidal albendazole $10 \%$ terhadap telur cacing Fasciola gigantica secara in vitro. Indonesia Medicus Veterinus 6(5): 363-369.

Bintara S, Astuti A, Panjono, Kusumastuti TA. 2018. Kualitas Sperma Domba Ekor Gemuk Pasca Pembekuan Sperma dengan Bantuan Micro Controller. Prosiding Spinosum Nasional Penelitian dan Pengembangan Peternakan Tropik 2018.Yogyakarta, 5 November 2018. Hlm. 173-176.

Bogar BCA, Tendean L, Turalaki. 2016. Pengaruh pemberian ekstrak pasak bumi (Eurycoma longifolia Jack) terhadap 
kualitas spermatozoa tikus Wistar (Rattus novergicus). J Biomed 4(1): 205- 209.

Frydrychova S, Opletal L, Maca KK, Lustykova A, Rozkot M, Lipensky J. 2011. Effects of herbal preparation on libido and semen quality in boars. Reprod Dom Anim 46(4): 573-578.

Garner DL, Hafez ESE. 2000. Spermatozoa and Seminal Plasma. Hafez, B., and Hafez, E.S.E (eds). In Reproduction in Farm Animals. $7^{\text {th }}$ Ed. Lippincott Williams and Wilkins, Philadelphia. Hlm. 96-109.

Hayati F, Widyasrini S, Hakim L, Ngatidjan, Mustofa. 2012. Pengaruh pemberian ekstrak akar pasak bumi terstandar terhadap gambaran histopatologi testis dan konsentrasi testoteron pada tikus. J Ilmu Kefarmasian Indonesia 10(1): 50-56.

Husnurrizal, Aritonang AS, Siregar TN, Armansyah T, Hafizuddin. 2021. Penambahan PGF2á dalam pengencer semen dapat meningkatkan motilitas pasca thawing motility spermatozoa domba waringin. Livest Anim Res 19(2): 210-216.

Juniarto AZ. 2010. Efek pemberian ekstrak Eurycoma longifolia dan Pimpinella alpina pada spermatogenesis tikus Spraque Dawley. Medical Veterinaria Indonesiana 44(1): 20-26.

Kusumawati ED, Utomo KN, Krisnaningsih ATN, Rahadi S. 2017. Kualitas semen kambing kacang dengan lama simpan yang berbeda pada suhu ruang menggunakan pengencer tris aminomethamin kuning telur. J Ilmu dan Peternakan Tropis 4(3): $1-10$.

Mughniati S, Sari DK, Rendrawan D, Rahim L. 2018. Pengaruh ekstrak biji kapuk (Ceiba pentandra Gaertn) sebagai obat kontrasepsi terhadap kualitas spermatozoa pada kucing lokal (Felis domestica). J Riset Vet Indonesia 2(1): 27-34.

Nahriyanti S, Ondho YS, Samsudewa D. 2017. Perbedaan kualitas makroskopis semen segar domba batur dalam flock mating dan pen mating. J Sain Pet Indonesia 12(2): 192 198.

Prastika Z, Susilowati SM, Agustono B, Safitri E, Fikri F, Prastiya RA. 2018. Motilitas dan viabilitas spermatozoa sapi Rambon di desa Kemiren Bayuwangi. J Med Vet 1(2):_3842.
Pratomo H, Supriatna I, Manalu W, Winarto A. 2012. Tingkat aktifitas sel endokrin penghasil folikel stimulating hormon (FSH) terkait pemberian pasak bumi (Eurycoma longifolia Jack). J Ilmu Kefarmasian Indonesia 1(1):_1-10.

Pratomo H, Yudi. 2016. Pemberian pasak bumi memengaruhi kadar testosteron dan spermatozoa kambing Peranakan Etawa. $J$ Kedokt Hewan 10(2): 148-152.

Purwono S. 2015. Khasiat dan Keamanan Ektrak Air Akar Pasak Bumi (Eurycoma longifolia Jack) Terstandar Pada Pria Gangguan Seksual. Disertasi. Yogyakarta. Universitas Gadjah Mada.

Puspitasari S, Sulistiawati E, Basar M, Farajalilah A. 2015. Efektivitas ivermectin dan albendazole dalam melawan ostertalgia pada anakan domba di Bogor, Indonesia. $J$ Ilmu Pertanian Indonesia 20(3): 257-264.

Rahayu YG, Siregar TN, Gholib, Thasmi CNT, Herrialfian, Daud R, Zuhrawati, Hamdan, Rasmaidar. 2018. Perbandingan konsentrasi progesteron selama siklus birahi pada domba Waringin yang diinduksi PGF2á dan GnRH. J Ilmu Peternakan Terpadu 6(2): 101-105.

Soehadi K, Arsyad KM. 1983. Analisis Sperma. Surabaya. Airlangga University Press Hlm. 16-22.

Toelihere MR. 1993. Inseminasi Buatan pada Ternak. Cetakan ke-6. Angkasa, Bandung. Hlm. 21-23.

Wahid AS, Yunus JM. 1995. Level of testosterone in blood plasma of selected rams. AsiaAustralasian J Anim Sci 8(6): 583-585.

Wahyuni LT, Nurdin AE, Anas E. 2015. Pengaruh gangguan tidur terhadap kadar hormon testosteron dan jumlah spermatozoa pada tikus jantan Wistar. J Kesehatan Andalas 4(3): 835-840.

WHO. 1998. Laboratory Manual for the Examination of Human Semen and SpermCervical Mucus Interaction. $4 t h$ ed. England. Cambridge University Press. Hlm. 36-40.

Zubir, Priyanto R, Gurnadi E, Manalu W, Winugroho HM. 2011. Produksi dan komposisi fisik karkas domba jantan priangan yang disuplementasi peptida pasak bumi (Eurycoma longifolia Jack). J Ilmu Ternak Vet 16(3): 184-193. 